\title{
Stabilisation of Collagen Sponges by Glutaraldehyde Vapour Crosslinking
}

\author{
Yong Y. Peng, Veronica Glattauer, and John A. M. Ramshaw \\ CSIRO Manufacturing, Bayview Avenue, Clayton, VIC 3169, Australia \\ Correspondence should be addressed to Veronica Glattauer; veronica.glattauer@csiro.au
}

Received 23 February 2017; Accepted 11 April 2017; Published 9 May 2017

Academic Editor: Kheng-Lim Goh

Copyright ( 2017 Yong Y. Peng et al. This is an open access article distributed under the Creative Commons Attribution License, which permits unrestricted use, distribution, and reproduction in any medium, provided the original work is properly cited.

\begin{abstract}
Glutaraldehyde is a well-recognised reagent for crosslinking and stabilising collagens and other protein-based materials, including gelatine. In some cases, however, the use of solutions can disrupt the structure of the material, for example, by causing rapid dispersion or distortions from surface interactions. An alternative approach that has been explored in a number of individual cases is the use of glutaraldehyde vapour. In this study, the effectiveness of a range of different glutaraldehyde concentrations in the reservoir providing vapour, from $5 \%$ to $25 \%(\mathrm{w} / \mathrm{v})$, has been explored at incubation times from $5 \mathrm{~h}$ to $48 \mathrm{~h}$ at room temperature. These data show the effectiveness of the glutaraldehyde vapour approach for crosslinking collagen and show that materials with defined, intermediate stability could be obtained, for example, to control resorption rates in vivo.
\end{abstract}

\section{Introduction}

Glutaraldehyde (GA) has been used extensively as a crosslinking agent for collagen-based biomedical materials [1]. This includes its use in tissue based devices such as heart valve replacements $[2,3]$ and for tissue biosynthetic products [4] Also, it has been used for products based on purified collagen, including collagen pastes [5] and freeze dried collagen sponges [6]. Most recently it has been examined for stabilisation of recombinant collagen products [7].

Despite its extensive use in medical products, concerns remain still about its potential cytotoxicity [8-10] and it being a causative agent of nonspecific tissue calcification [11]. Certainly, nonspecific calcification of biologically derived heart valves is a significant issue and leads to loss of function and the need for revision [12], although catastrophic failure is not a normal issue. Various methods have been examined to reduce this calcification $[13,14]$. It has been suggested that the cytotoxicity and calcification arise from the propensity of GA to form reactive polymers, particularly at the neutral $\mathrm{pH}$ conditions normally used for tissue and collagen stabilisation. At acidic conditions, for example, around pH 3-pH 4, GA is found predominantly as a monomer but taking the reagent to neutral $\mathrm{pH}$ leads to formation of polymeric forms [15]. Crosslinking will occur at $\mathrm{pH} 4$, but it is slow and gives materials of lower thermal stability [16].
Other approaches have looked at ways to minimise the amount of GA polymer present during neutral $\mathrm{pH}$ stabilisation. One approach is to stabilise collagen with GA at an elevated temperature, for example, up to $50^{\circ} \mathrm{C}$ [17], which is less than typical tissue shrinkage temperatures. Examination of GA solutions at elevated temperature, for example, by NMR spectroscopy, shows an increase in free aldehyde content [18].

Another approach is to use GA vapour, which has been used in the preparation of collagen-based biomedical materials [19-21]. In particular, it has been used for samples that are initially hard to handle without damage, including sponges from bacterial collagens which may disperse in solvents [7]. More studies, however, have been done on the denatured form of collagen, gelatine, especially on electrospun gelatine materials [22-24], as well as on a number of protein composite materials that include notionally collagen or gelatine $[25,26]$. Electrospun gelatine can also be formed unintentionally, from electrospinning of collagen in harsh solvents [27], although more recently benign solvents have been used for electrospinning of collagen without associated denaturation $[28,29]$. Electrospun films of collagen or gelatine are frequently quite fragile, so the use of vapour phase crosslinking has clear advantages over solution methods.

Previous GA vapour stabilisation studies have used a wide variety of conditions with variations in time of exposure, 
GA concentration in the reservoir, and reaction temperature, with no preferred procedure emerging. In the present study, we have examined a range of conditions, all at room temperature to understand better the extent and rate of crosslinking that can occur.

\section{Materials and Methods}

2.1. Collagen Sponge Preparation. Bovine type I collagen was purified from yearling hides obtained from a local abattoir using the well-established method [30] of pepsin solubilisation of minced, unhaired dermis, using $1 \mathrm{mg} / \mathrm{ml}$ pepsin (Sigma-Aldrich) in $100 \mathrm{mM}$ acetic acid (Merck). Fractionation of different collagens and purification of type I collagen was by $\mathrm{NaCl}$ precipitation in acetic acid and then at $\mathrm{pH} 7.2$, as previously described [30, 31]. Purified bovine type I collagen at $10 \mathrm{mg} / \mathrm{ml}$ in $50 \mathrm{mM}$ acetic acid was used to prepare freeze dried collagen sponges, around $3 \mathrm{~mm}$ thick. Circular samples $6 \mathrm{~mm}$ in diameter for glutaraldehyde (GA) treatment and analysis were cut from the sponge sheets with a biopsy punch. Except where otherwise noted all other chemicals were of the highest grade readily available and obtained from Merck (Victoria).

2.2. Glutaraldehyde Treatments. For GA vapour crosslinking, GA was obtained as a 50\% (w/v) stock solution (ProSciTech, Thuringowa, QLD). For crosslinking, >20 ml GA solutions of various concentrations made by diluting the stock GA solution with water, from $5 \%$ up to $25 \%(\mathrm{w} / \mathrm{v})$, were held in the lower part of glass desiccators in $70 \mathrm{~mm}$ dishes. Cut sponge disks were held in glass dishes above these solutions, allowing ready access to vapour, and the desiccator lid was placed to seal the chamber. Samples were removed at selected times, up to $48 \mathrm{~h}$, of GA vapour exposure. Control samples, with no GA treatment, were handled in a similar manner but were held over water and had no exposure to GA. Samples for Differential Scanning Calorimetry (DSC) analysis were washed with $40 \mathrm{mM}$ glycine for $3 \mathrm{~h}$ and then washed in MilliQ water and air dried. Other samples were held isolated, open to a stream of clean air for at least $12 \mathrm{~h}$ prior to any further analysis.

2.3. Differential Scanning Calorimetry. The thermal stability of untreated and GA vapour treated collagen disks were determined by DSC using a Mettler Toledo DSC821 instrument. The collagen sponge disks were between 0.8 and $0.9 \mathrm{mg}$ each and were rehydrated in phosphate buffered saline (PBS) prior to analysis. A heating rate of $5^{\circ} \mathrm{C} / \mathrm{min}$ was used. Data were averaged from separate sample determinations, with at least 2 determinations for each condition. The range of values obtained was typically around $1^{\circ} \mathrm{C}$ for each condition tested.

2.4. Scanning Electron Microscopy. Samples were examined after Ir coating ( $30 \mathrm{sec}, 60 \mathrm{~mA}$ ) using a Cressington 208HR sputter coater using a Zeiss Merlin Gemini 2 FESEM instrument.

\section{Results and Discussion}

GA is a widely used crosslinking agent for collagen, gelatine, and many other proteins that is normally used at a dilute concentration, for example, 0.1 to $2.0 \%(\mathrm{w} / \mathrm{v})$, in aqueous solution [1] or less frequently in organic solvents [32]. In some cases, the nature of the sample makes it unsuitable for stabilisation in solution. In these instances, using GA vapour has proved a suitable alternative.

Previously a wide range of isolated treatment conditions have been used (Table 1), in which variations in temperature and in the GA concentration in the vapour reservoir have been used. The present study has compared the effects of concentration and time variations on the effectiveness of collagen crosslinking. The effectiveness of the crosslinking has been determined by the increase in the collagen melting temperature $\left(T_{\mathrm{m}}\right.$, denaturation temperature). This method allows moderately rapid, reproducible determinations, but the high rate of heating, $5^{\circ} \mathrm{C} / \mathrm{min}$, can lead to a slight increase in values, especially at lower temperatures, compared with methods that use a lower heating rate, where a $T_{\mathrm{m}}$ around $4^{\circ} \mathrm{C}$ lower may be observed.

The present study has examined concentrations ranging from $5 \%(\mathrm{w} / \mathrm{v}) \mathrm{GA}$ up to $25 \% \mathrm{GA}(\mathrm{w} / \mathrm{v})$ in aqueous solution and incubation time up to $48 \mathrm{~h}$ (Figure 1). The temperature used was room temperature, which had most frequently been used by others (Table 1). Previously, higher temperatures have been used in some studies [20, 22], where increased speed of crosslinking is expected, in part from the increase in GA vapour pressure. For example, the GA vapour pressure increases around 7 -fold for a $15 \%(\mathrm{w} / \mathrm{v})$ solution between room temperature $\left(20^{\circ} \mathrm{C}, 32 \mathrm{ppm}\right)$ and $40^{\circ} \mathrm{C}(226 \mathrm{ppm})$ [42].

These present data show that essentially full crosslinking, $T_{\mathrm{m}}>80^{\circ} \mathrm{C}$, can be achieved by using $20 \%$ or $25 \%(\mathrm{w} / \mathrm{v})$ reservoir solutions for $24 \mathrm{~h}$ or $48 \mathrm{~h}$. This is consistent with previously report $T_{\mathrm{m}}$ data $[20,21]$, where a $T_{\mathrm{m}}$ of $>80^{\circ} \mathrm{C}$ was reported for a collagen sponge over $25 \%(\mathrm{w} / \mathrm{v}) \mathrm{GA}$ at room temperature for $24 \mathrm{~h} \mathrm{[21]} \mathrm{and} \mathrm{similarly} \mathrm{a} T_{\mathrm{m}}$ of $>80^{\circ} \mathrm{C}$ was reported for a collagen film over $8 \%(\mathrm{w} / \mathrm{v}) \mathrm{GA}$ at $37^{\circ} \mathrm{C}$ after $8 \mathrm{~h}$ [20]. $T_{\mathrm{m}}$ provides a good quantitative measure for crosslinking but is not always reported. Often, the physical appearance and stability of materials are quoted under varying conditions, such as in acid solution. For gelatine samples, a $T_{\mathrm{m}}$ cannot be given as the gelatine is already denatured (from collagen). The efficiency of crosslinking for GA treated gelatine samples can be estimated by examining the stability of the material to proteolysis. However, the conditions used often vary between studies, making comparisons difficult.

At lower reservoir concentrations of GA, full crosslinking did not seem to occur, even after $48 \mathrm{~h}$ incubation time (Figure 1). Further, it appeared that for lower concentrations the extent of crosslinking, as shown by $T_{\mathrm{m}}$ values, was appearing to approach a maximum value dependent on the concentration being used (Figure 1). Samples incubated over $5 \%(\mathrm{w} / \mathrm{v})$ GA showed $T_{\mathrm{m}}$ values in the mid-50 $\mathrm{C}$ range after $24 \mathrm{~h}$, and these values did not increase much after $48 \mathrm{~h}$ incubation. Samples over $10 \%$ and $15 \%$ (w/v) GA solutions may also be approaching maximum values which are in the mid- $70^{\circ} \mathrm{C}$ range (Figure 1) and lower than the $T_{\mathrm{m}}$ values of $>80^{\circ} \mathrm{C}$ found with higher GA concentrations. These apparent plateau values dependent on the concentration of GA in the reservoir have the potential to provide sample series of varying crosslinking, for example, for studies on resorption 
TABLE 1: Examples of previously reported conditions for GA vapour stabilisation of collagen and gelatine materials.

\begin{tabular}{|c|c|c|c|c|c|}
\hline Substrate & Format & Temperature & $\% \mathrm{GA}$ & Time & Reference \\
\hline $\begin{array}{l}\text { Collagen } \\
\text { (Limed } \\
\text { bovine) }\end{array}$ & $\begin{array}{l}\text { Reconstituted } \\
\text { Fibrils }\end{array}$ & RT & $25 \%$ & $24 \mathrm{~h}, 48 \mathrm{~h}$ & Kato et al. [19] \\
\hline $\begin{array}{l}\text { Collagen } \\
\text { (Bovine) }\end{array}$ & $\begin{array}{l}\text { Reconstituted } \\
\text { Fibrils }\end{array}$ & RT & $25 \%$ & $96 \mathrm{~h}$ & Law et al. [33] \\
\hline $\begin{array}{l}\text { Collagen } \\
\text { (Bovine) }\end{array}$ & Film & $37^{\circ} \mathrm{C}$ & $8 \%$ & $\begin{array}{l}\text { Various } \\
3 \mathrm{~h} \text { to } 72 \mathrm{~h}\end{array}$ & Barbani et al. [20] \\
\hline $\begin{array}{l}\text { Collagen } \\
\text { (Bovine) }\end{array}$ & $\begin{array}{l}\text { Electrospun } \\
\text { mat }\end{array}$ & RT & (Not stated) & $24 \mathrm{~h}$ & $\begin{array}{c}\text { Matthews et al. } \\
{[34]}\end{array}$ \\
\hline $\begin{array}{l}\text { Collagen } \\
\text { (Bovine) }\end{array}$ & Sponges & $\mathrm{RT}$ & $25 \%$ & $4 \mathrm{~h}, 8 \mathrm{~h}, 24 \mathrm{~h}$ & Lickorish et al. [21] \\
\hline $\begin{array}{l}\text { Collagen } \\
\text { (Bovine) }\end{array}$ & $\begin{array}{l}\text { Reconstituted } \\
\text { Fibrils }\end{array}$ & RT & $25 \%$ & $\begin{array}{l}\text { Various, } \\
1 \mathrm{~h} \text { to } 24 \mathrm{~h}\end{array}$ & Rho et al. [35] \\
\hline $\begin{array}{l}\text { Collagen } \\
\text { (Bovine) }\end{array}$ & $\begin{array}{c}\text { Electrospun } \\
\text { mat }\end{array}$ & RT & $25 \%$ & $24 \mathrm{~h}$ & Yang et al. [36] \\
\hline $\begin{array}{l}\text { Bacterial } \\
\text { Collagen }\end{array}$ & Sponge & RT & $20 \%$ & $18 \mathrm{~h}$ & Peng et al. [7] \\
\hline $\begin{array}{l}\text { Collagen } \\
\text { (Bovine) }\end{array}$ & $\begin{array}{l}\text { Electrospun } \\
\text { mat }\end{array}$ & RT & $25 \%$ & $8 \mathrm{~h}$ & Takeda et al. [37] \\
\hline $\begin{array}{l}\text { Gelatine } \\
\text { (Fish skin) }\end{array}$ & $\begin{array}{l}\text { Electrospun } \\
\text { mat }\end{array}$ & $37^{\circ} \mathrm{C}$ & 50 vol $\%$ & $3 \mathrm{~h}$ & $\begin{array}{l}\text { Songchotikunpan } \\
\text { et al. [22] }\end{array}$ \\
\hline Gelatine & $\begin{array}{l}\text { Electrospun } \\
\text { mat }\end{array}$ & & $0.5 \%$ & $19 \mathrm{~h}$ & Sisson et al. [38] \\
\hline $\begin{array}{l}\text { Gelatine } \\
\text { (Porcine) }\end{array}$ & $\begin{array}{c}\text { Electrospun } \\
\text { mat }\end{array}$ & $37^{\circ} \mathrm{C}$ & "Saturated" & $5 \min$ & $\begin{array}{c}\text { Dheraprasart et al. } \\
\text { [39] }\end{array}$ \\
\hline $\begin{array}{l}\text { Gelatine } \\
\text { (A-type, } \\
\text { B-type) }\end{array}$ & $\begin{array}{c}\text { DHT-treated } \\
\text { Electrospun } \\
\text { mat }\end{array}$ & $4^{\circ} \mathrm{C}$ & $\begin{array}{c}0.06 \% \text { in } \\
\text { acetone } / \mathrm{HCl}\end{array}$ & $48 \mathrm{~h}$ & $\begin{array}{c}\text { Ratanavaraporn et } \\
\text { al. [40] }\end{array}$ \\
\hline $\begin{array}{l}\text { Gelatine } \\
\text { (A-type) }\end{array}$ & $\begin{array}{c}\text { Electrospun } \\
\text { mat }\end{array}$ & RT & $1.5 \%$ in $\mathrm{EtOH}$ & $48 \mathrm{~h}$ & Zha et al. [23] \\
\hline $\begin{array}{l}\text { Gelatine } \\
\text { (Fish skin) }\end{array}$ & $\begin{array}{l}\text { Electrospun } \\
\text { mat }\end{array}$ & $40^{\circ} \mathrm{C}$ & $5 \%$ & $\begin{array}{c}\text { Various, } \\
0.5 \mathrm{~h} \text { to } 24 \mathrm{~h}\end{array}$ & Gomes et al. [24] \\
\hline $\begin{array}{l}\text { Gelatine } \\
\text { (Fish skin) }\end{array}$ & $\begin{array}{l}\text { Electrospun } \\
\text { mat }\end{array}$ & $40^{\circ} \mathrm{C}$ & $5 \%$ & $5 \mathrm{~h}$ & Gomes et al. [41] \\
\hline
\end{tabular}

RT: Room temperature.

rate, similar to those obtained from the use of different GA concentrations in solution stabilisation [43].

GA vapour crosslinking has the advantage for any porous sample that by avoiding surface tension and repeated freeze drying that are found with solution approaches the use of vapour leads to negligible changes to the collagen organisation and topology. SEM studies (Figure 2), show little if any changes in the collagen sponge structure in control untreated material (Figure 2(a)) and one extensively stabilised $(20 \%$ (w/v) GA, 24 h) by GA vapour (Figure 2(b)).

In the present study, we have examined purified collagen with no additions. GA vapour stabilisation can also be used for composite materials based on collagen and gelatine. These include, for example, mixtures of collagen or gelatine with other proteins $[25,26]$, or with other components including carbohydrates [44], polymers [45], and mineral [46].

In addition to mixtures, collagen and gelatine can be used as external coatings during coaxial spinning [47].
Several previous studies have used GA vapour crosslinking collagen-based materials for cell growth, and these studies have consistently shown that the resultant crosslinking is not cytotoxic [7, 21, 33-35, 37], even when higher GA concentrations are used at longer time points [7, 21, 33, 35]. This is consistent with the GA being reactive as the monomer and not allowing a significant build-up of polymers in the stabilised material. Other studies have shown the enhanced mechanical properties arising from GA vapour crosslinking fabricated of materials $[19,35,36]$.

\section{Conclusion}

The present study has demonstrated the effectiveness of GA crosslinking over a range of conditions. It has shown that essentially full crosslinking can be obtained for collagen sponges with treatment with $20 \%$ or $25 \%$ GA vapour for 24 or 


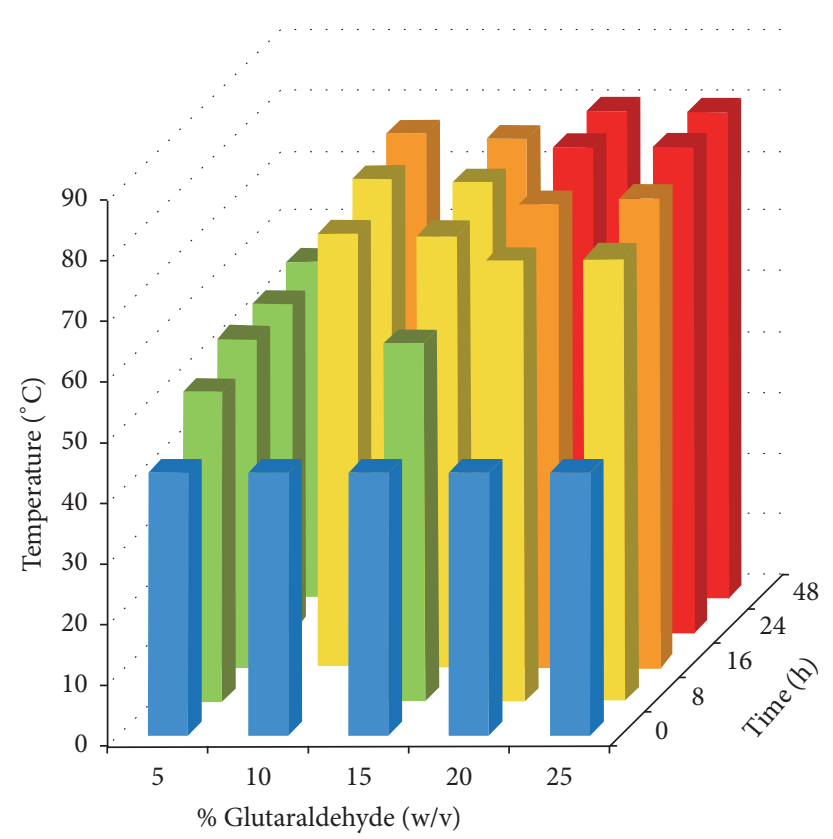

$T_{\mathrm{m}}$ values $\left({ }^{\circ} \mathrm{C}\right)$

\begin{tabular}{lccccc}
\hline & & \multicolumn{5}{c}{ Time $(\mathrm{h})$} \\
GA\% & 0 & 8 & 16 & 24 & 48 \\
\hline 5 & 43.4 & 51.1 & 54.1 & 54.2 & 55.4 \\
10 & 43.4 & n.d. & 71.5 & 74.9 & 76.7 \\
15 & 43.4 & 59.1 & 71.5 & 74.3 & 75.8 \\
20 & 43.4 & 72.8 & 76.3 & 80.1 & 80.4 \\
25 & 43.4 & 73.3 & 77.3 & 80.2 & 80.3 \\
\hline
\end{tabular}

FIGURE 1: Bar diagram, showing the melting temperature, $T_{\mathrm{m}}$, of collagen sponges treated with varying amounts of aqueous GA vapour for various time periods. Red bars indicate $T_{\mathrm{m}}>80^{\circ} \mathrm{C}$, orange bars indicate $75^{\circ} \mathrm{C}<T_{\mathrm{m}}<80^{\circ} \mathrm{C}$, yellow bars indicate $70^{\circ} \mathrm{C}<T_{\mathrm{m}}<75^{\circ} \mathrm{C}$, green bars indicate $50^{\circ} \mathrm{C}<T_{\mathrm{m}}<70^{\circ} \mathrm{C}$, and blue bars indicate $T_{\mathrm{m}}<50^{\circ} \mathrm{C}$, as found for the average value of control untreated sponges. A single average $T_{\mathrm{m}}$ value for control untreated samples was obtained and this average value was used in each of the different \% GA treatment series. $T_{\mathrm{m}}$ values are given below the diagram. n.d.: not determined.

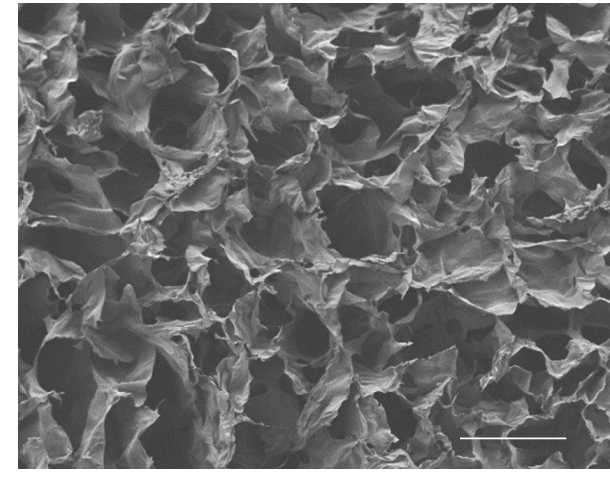

(a)

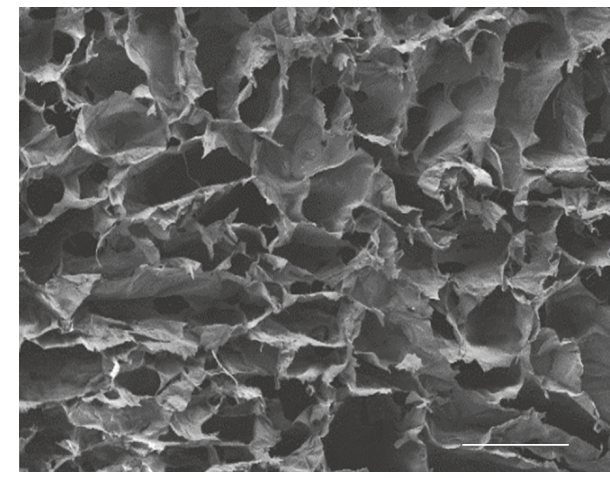

(b)

FIGURE 2: FESEM examination of collagen sponges. (a) Control untreated sponges, (b) GA vapour stabilised sponge; $25 \%$ (w/v) GA, $24 \mathrm{~h}$ at room temperature. Bar $=100 \mu \mathrm{m}$. 
$48 \mathrm{~h}$ at room temperature. Intermediate degrees of crosslinking may be obtained by varying the GA concentration. These observations, and the understanding of the variation in crosslinking through changes in GA concentration and time, should be useful in designing the preferred crosslinking characteristics for collagens and gelatines and in composites based on these protein materials. The use of GA vapour crosslinking is particularly useful for porous materials that are not easily handled, providing stability. Subsequently, additional solution based crosslinking could be used to augment the stability if necessary or to introduce chemical modifications while maintaining a stable structure.

\section{Disclosure}

John A. M. Ramshaw's present address is Department of Surgery, St. Vincent's Hospital, University of Melbourne, Melbourne, VIC 3065, Australia.

\section{Conflicts of Interest}

The authors declare that there are no conflicts of interest regarding the publication of this paper.

\section{Acknowledgments}

The authors thank Dr. Wendy Tian for advice on DSC and Mark Greaves for assistance with FESEM.

\section{References}

[1] E. Khor, "Methods for the treatment of collagenous tissues for bioprostheses," Biomaterials, vol. 18, no. 2, pp. 95-105, 1997.

[2] N. Zuhdi, W. Hawley, V. Voehl, W. Hancock, J. Carey, and A. Greer, "Porcine aortic valves as replacements for human heart valves," Annals of Thoracic Surgery, vol. 17, no. 5, pp. 479-491, 1974.

[3] M. I. Ionescu, A. P. Tandon, D. A. S. Mary, and A. Abid, "Heart valve replacement with the Ionescu Shiley pericardial xenograft," Journal of Thoracic and Cardiovascular Surgery, vol. 73, no. 1, pp. 31-42, 1977.

[4] J. A. M. Ramshaw, D. E. Peters, J. A. Werkmeister, and V. Ketharanathan, "Collagen organization in mandrel-grown vascular grafts," Journal of Biomedical Materials Research, vol. 23, no. 6, pp. 649-660, 1989.

[5] J. M. McPherson, P. W. Ledger, S. Sawamura et al., "The preparation and physicochemical characterization of an injectable form of reconstituted, glutaraldehyde cross-linked, bovine corium collagen," Journal of Biomedical Materials Research, vol. 20, no. 1, pp. 79-92, 1986.

[6] R. F. Oliver, R. A. Grant, R. W. Cox, and A. Cooke, "Effect of aldehyde cross-linking on human dermal collagen implants in the rat," British Journal of Experimental Pathology, vol. 61, no. 5, pp. 544-549, 1980.

[7] Y. Y. Peng, A. Yoshizumi, S. J. Danon et al., "A Streptococcus pyogenes derived collagen-like protein as a non-cytotoxic and non-immunogenic cross-linkable biomaterial," Biomaterials, vol. 31, no. 10, pp. 2755-2761, 2010.

[8] D. P. Speer, M. Chvapil, C. D. Eskelson, and J. Ulreich, "Biological effects of residual glutaraldehyde in glutaraldehyde-tanned collagen biomaterials," Journal of Biomedical Materials Research, vol. 14, no. 6, pp. 753-764, 1980.

[9] E. Gendler, S. Gendler, and M. E. Nimni, "Toxic reactions evoked by glutaraldehyde-fixed pericardium and cardiac valve tissue bioprosthesis," Journal of Biomedical Materials Research, vol. 18, no. 7, pp. 727-736, 1984.

[10] L. M. Delgado, K. Fuller, and D. I. Zeugolis, "Collagen crosslinking: biophysical, biochemical, and biological response analysis," Tissue Engineering Part A, 2017.

[11] R. J. Levy, F. J. Schoen, F. S. Sherman, J. Nichols, M. A. Hawley, and S. A. Lund, "Calcification of subcutaneously implanted type I collagen sponges. Effects of formaldehyde and glutaraldehyde pretreatments," American Journal of Pathology, vol. 122, no. 1, pp. 71-82, 1986.

[12] F. J. Schoen and R. J. Levy, "Pathology of substitute heart valves: new concepts and developments," Journal of Cardiac Surgery, vol. 9, pp. 222-227, 1994.

[13] M. K. Dewanjee, E. Solis, J. Lanker et al., "Effect of diphosphonate binding to collagen upon inhibition of calcification and promotion of spontaneous endothelial cell coverage on tissue valve prostheses," ASAIO transactions/American Society for Artificial Internal Organs, vol. 32, no. 1, pp. 24-29, 1986.

[14] N. Vyavahare, D. Hirsch, E. Lerner et al., "Prevention of bioprosthetic heart valve calcification by ethanol preincubation: efficacy and mechanisms," Circulation, vol. 95, no. 2, pp. 479-488, 1997.

[15] K. E. Rasmussen and J. Albrechtsen, "Glutaraldehyde. The influence of $\mathrm{pH}$, temperature, and buffering on the polymerization rate," Histochemistry, vol. 38, no. 1, pp. 19-26, 1974.

[16] D. E. Peters, L. J. Stephens, and J. A. M. Ramshaw, "Examination of collagen tanning by glutaraldehyde using isometric tension measurements," Das Leder, vol. 41, no. 7, pp. 129-133, 1990.

[17] J. M. Ruijgrok, J. R. de Wijn, and M. E. Boon, "Glutaraldehyde crosslinking of collagen: effects of time, temperature, concentration and presoaking as measured by shrinkage temperature," Clinical Materials, vol. 17, no. 1, pp. 23-27, 1994.

[18] C. E. Holloway and F. H. Dean, " ${ }^{13}$ C-NMR study of aqueous glutaraldehyde equilibria," Journal of Pharmaceutical Sciences, vol. 64, no. 6, pp. 1078-1079, 1990.

[19] Y. P. Kato, D. L. Christiansen, R. A. Hahn, S.-J. Shieh, J. D. Goldstein, and F. H. Silver, "Mechanical properties of collagen fibres: a comparison of reconstituted and rat tail tendon fibres," Biomaterials, vol. 10, no. 1, pp. 38-42, 1989.

[20] N. Barbani, P. Giusti, L. Lazzeri, G. Polacco, and G. Pizzirani, "Bioartificial materials based on collagen: 1. Collagen crosslinking with gaseous glutaraldehyde," Journal of Biomaterials Science, Polymer Edition, vol. 7, no. 6, pp. 461-469, 1996.

[21] D. Lickorish, J. A. M. Ramshaw, J. A. Werkmeister, V. Glattauer, and C. R. Howlett, "Collagen-hydroxyapatite composite prepared by biomimetic process," Journal of Biomedical Materials Research - Part A, vol. 68, no. 1, pp. 19-27, 2004.

[22] P. Songchotikunpan, J. Tattiyakul, and P. Supaphol, "Extraction and electrospinning of gelatin from fish skin," International Journal of Biological Macromolecules, vol. 42, no. 3, pp. 247-255, 2008.

[23] Z. Zha, W. Teng, V. Markle, Z. Dai, and X. Wu, "Fabrication of gelatin nanofibrous scaffolds using ethanol/phosphate buffer saline as a benign solvent," Biopolymers, vol. 97, no. 12, pp. 10261036, 2012.

[24] S. R. Gomes, G. Rodrigues, G. G. Martins, C. M. R. Henriques, and J. C. Silva, "In vitro evaluation of crosslinked electrospun 
fish gelatin scaffolds," Materials Science and Engineering C, Materials for Biological Applications, vol. 33, no. 3, pp. 1219-1227, 2013.

[25] I.-S. Yeo, J.-E. Oh, L. Jeong et al., "Collagen-based biomimetic nanofibrous scaffolds: preparation and characterization of collagen/silk fibroin bicomponent nanofibrous structures," Biomacromolecules, vol. 9, no. 4, pp. 1106-1116, 2008.

[26] E. Tamimi, D. C. Ardila, D. G. Haskett et al., "Biomechanical comparison of glutaraldehyde-crosslinked gelatin fibrinogen electrospun scaffolds to porcine coronary arteries," Journal of Biomechanical Engineering, vol. 138, no. 1, Article ID 011001, 2016.

[27] D. I. Zeugolis, S. T. Khew, E. S. Y. Yew et al., "Electro-spinning of pure collagen nano-fibres-just an expensive way to make gelatin?” Biomaterials, vol. 29, no. 15, pp. 2293-2305, 2008.

[28] B. Dong, O. Arnoult, M. E. Smith, and G. E. Wnek, "Electrospinning of collagen nanofiber scaffolds from benign solvents," Macromolecular Rapid Communications, vol. 30, no. 7, pp. 539$542,2009$.

[29] A. Elamparithi, A. M. Punnoose, and S. Kuruvilla, "Electrospun type 1 collagen matrices preserving native ultrastructure using benign binary solvent for cardiac tissue engineering," Artificial Cells, Nanomedicine and Biotechnology, vol. 44, no. 5, pp. 13181325, 2016.

[30] E. J. Miller and R. K. Rhodes, "Preparation and characterization of the different types of collagen," Methods in Enzymology, vol. 82, pp. 33-64, 1982.

[31] R. L. Trelstad, V. M. Catanese, and D. F. Rubin, "Collagen fractionation: separation of native types I, II and III by differential prectipitation," Analytical Biochemistry, vol. 71, no. 1, pp.114-118, 1976.

[32] P. F. Gratzer, C. A. Pereira, and J. M. Lee, "Solvent environment modulates effects of glutaraldehyde crosslinking on tissuederived biomaterials," Journal of Biomedical Materials Research, vol. 31, no. 4, pp. 533-543, 1996.

[33] J. K. Law, J. R. Parsons, F. H. Silver, and A. B. Weiss, "An evaluation of purified reconstituted type 1 collagen fibers," Journal of Biomedical Materials Research, vol. 23, no. 9, pp. 961-977, 1989.

[34] J. A. Matthews, G. E. Wnek, D. G. Simpson, and G. L. Bowlin, "Electrospinning of collagen nanofibers," Biomacromolecules, vol. 3, no. 2, pp. 232-238, 2002.

[35] K. S. Rho, L. Jeong, G. Lee et al., "Electrospinning of collagen nanofibers: effects on the behavior of normal human keratinocytes and early-stage wound healing," Biomaterials, vol. 27, no. 8, pp. 1452-1461, 2006.

[36] L. Yang, C. F. C. Fitié, K. O. van der Werf, M. L. Bennink, P. J. Dijkstra, and J. Feijen, "Mechanical properties of single electrospun collagen type I fibers," Biomaterials, vol. 29, no. 8, pp. 955-962, 2008.

[37] N. Takeda, K. Tamura, R. Mineguchi et al., "In situ cross-linked electrospun fiber scaffold of collagen for fabricating cell-dense muscle tissue," Journal of Artificial Organs, vol. 19, no. 2, pp. 141148, 2016.

[38] K. Sisson, C. Zhang, M. C. Farach-Carson, D. B. Chase, and J. F. Rabolt, "Evaluation of cross-linking methods for electrospun gelatin on cell growth and viability," Biomacromolecules, vol. 10, no. 7, pp. 1675-1680, 2009.

[39] C. Dheraprasart, S. Rengpipat, P. Supaphol, and J. Tattiyakul, "Morphology, release characteristics, and antimicrobial effect of nisin-loaded electrospun gelatin fiber mat," Journal of Food Protection, vol. 72, no. 11, pp. 2293-2300, 2009.
[40] J. Ratanavaraporn, R. Rangkupan, H. Jeeratawatchai, S. Kanokpanont, and S. Damrongsakkul, "Influences of physical and chemical crosslinking techniques on electrospun type A and B gelatin fiber mats," International Journal of Biological Macromolecules, vol. 47, no. 4, pp. 431-438, 2010.

[41] S. R. Gomes, G. Rodrigues, G. G. Martins et al., "In vitro and in vivo evaluation of electrospun nanofibers of PCL, chitosan and gelatin: a comparative study," Materials Science and Engineering, C Materials for Biological Applications, vol. 46, pp. 348-358, 2015.

[42] J. D. Olson, “The vapor pressure of pure and aqueous glutaraldehyde," Fluid Phase Equilibria, vol. 150, no. 151, pp. 713-720, 1998.

[43] V. Glattauer, J. F. White, W.-B. Tsai et al., "Preparation of resorbable collagen-based beads for direct use in tissue engineering and cell therapy applications," Journal of Biomedical Materials Research-Part A, vol. 92, no. 4, pp. 1301-1309, 2010.

[44] Y.-F. Qian, K.-H. Zhang, F. Chen, Q.-F. Ke, and X.-M. Mo, "Cross-linking of gelatin and chitosan complex nanofibers for tissue-engineering scaffolds," Journal of Biomaterials Science, Polymer Edition, vol. 22, no. 8, pp. 1099-1113, 2011.

[45] X. Qiao, S. J. Russell, X. Yang, G. Tronci, and D. J. Wood, “Compositional and in vitro evaluation of nonwoven type I collagen/ poly-dl-lactic acid scaffolds for bone regeneration," Journal of Functional Biomaterials, vol. 6, no. 3, pp. 667-686, 2015.

[46] V. Thomas, D. R. Dean, M. V. Jose, B. Mathew, S. Chowdhury, and Y. K. Vohra, "Nanostructured biocomposite scaffolds based on collagen coelectrospun with nanohydroxyapatite," Biomacromolecules, vol. 8, no. 2, pp. 631-637, 2007.

[47] Y. Lu, H. Jiang, K. Tu, and L. Wang, "Mild immobilization of diverse macromolecular bioactive agents onto multifunctional fibrous membranes prepared by coaxial electrospinning," Acta Biomaterialia, vol. 5, no. 5, pp. 1562-1574, 2009. 

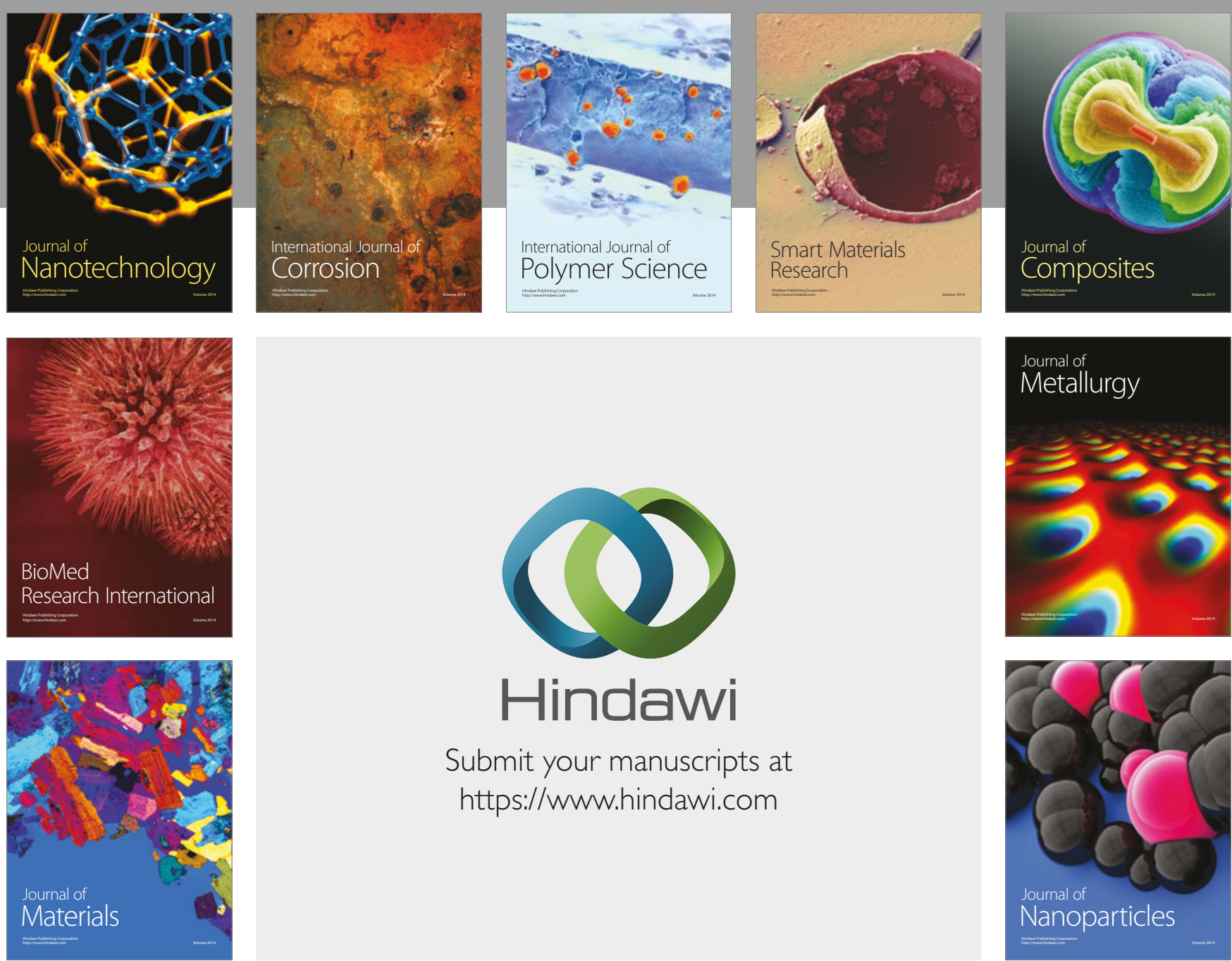

\section{Hindawi}

Submit your manuscripts at

https://www.hindawi.com
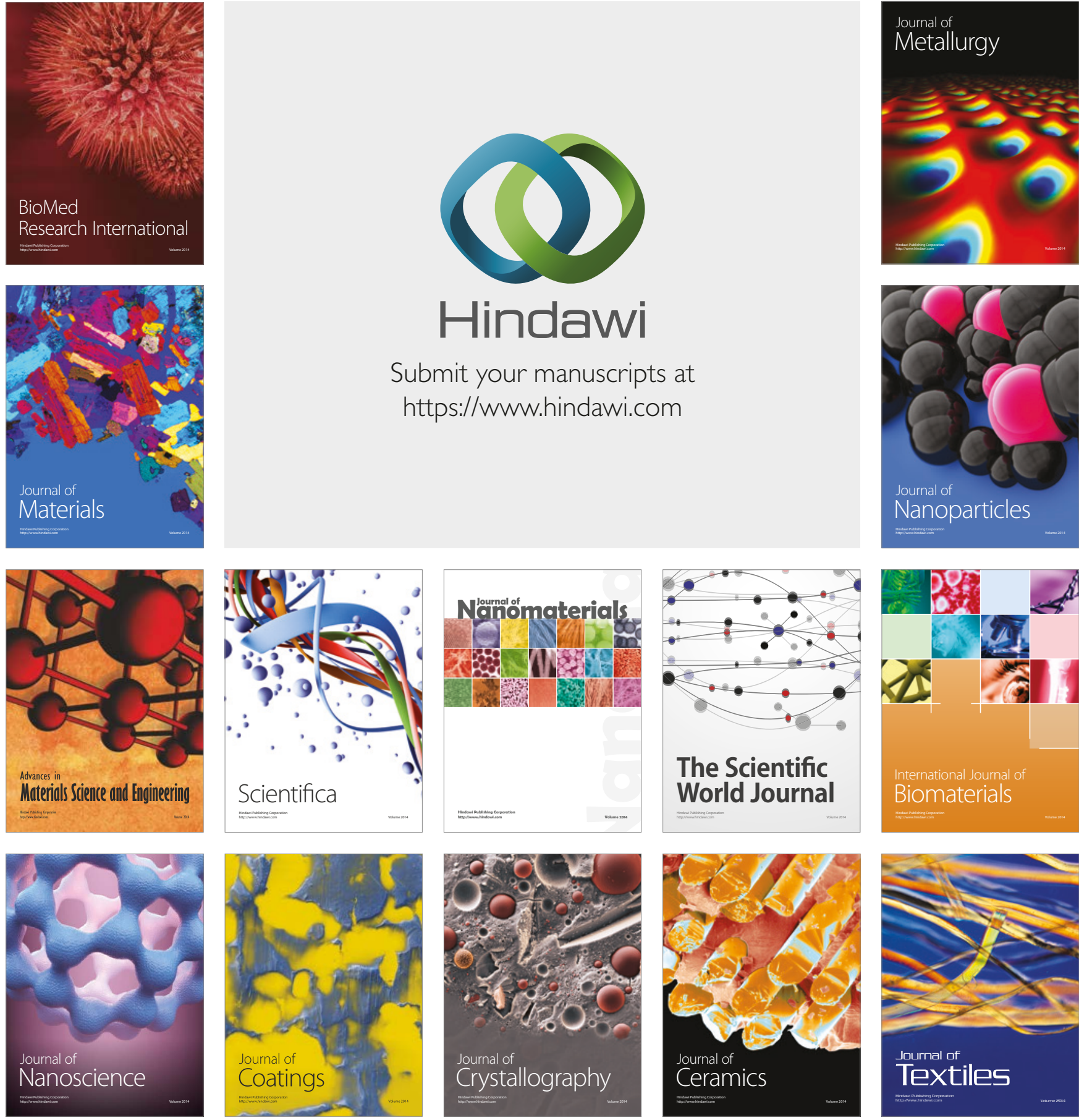

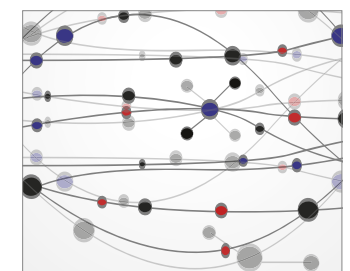

The Scientific World Journal
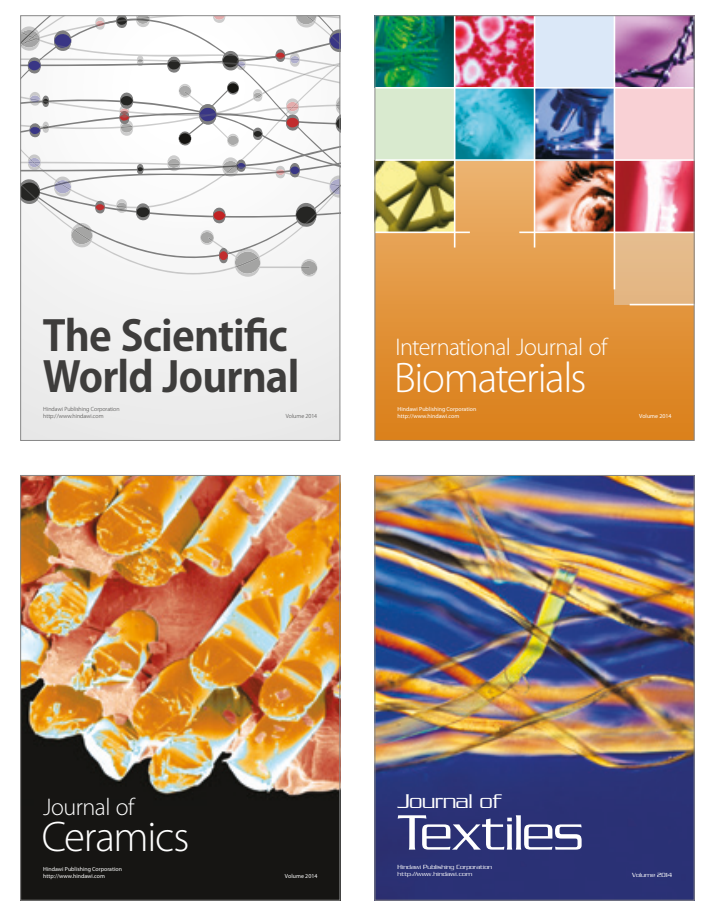